\title{
Injury prevention decision science
}

\section{Roderick J McClure}

I have not met an executive yet, who thinks they are poor decision-makers. I have not met many scientists who do not believe that data speak for themselves.

From an executive's perspective, poor decisions are simply the consequence of flawed (or insufficient) data, and from the scientist's perspective, poor decisions are what happens when decision-makers do not listen to scientists.

To address the problem, executives seek to obtain more and better data, and scientists advocate more loudly for data they produce.

But there is more to it than that. Decision-making is an active process somewhere between data inputs and public health outcome. There is a science that supports our understanding and optimal application of the decisionmaking process-decision science.

When it comes down to it, public health and thus injury prevention, is largely about making the right decisions. At the personal level, and the public one. By individuals, carers, industry (both public and private) and by civic leaders across a multitude of social institutions, governments and legislative bodies.

Given the ubiquity of modern Information and Communication Technology, most people in the world facing any given problem have access to the same data, yet everywhere in the world we see decisionmakers making different decisions. The resulting difference in public health outcomes is evident to all.

Correspondence to Dr Roderick J McClure, School of Rural Medicine, University of New England, Armidale, NSW 2350, Australia; rmcclure@une.edu.au
To extend a basic public health principle, we may not always know what the best public health decision is, but at least we can bring the quality of all public health decision-making up to the standard of the evident best.

So how do we do this?

First, by being as transparent about the decision-making process as we are about the scientific methods that generate data.

Second, by recognising the limitations of our current decision-making process, and working to advance the science on which it depends.

Third, work together in good faith and healthy scepticism, to (1) better understand the systems we are working with; (2) check, test and, where possible, seek to falsify our assumptions; and (3) obtain and input high-quality data for all critical aspects of the problem under consideration.

In following the above steps, we can ensure our decisions are, if not perfect, at least the best possible under current constraints.

What does all this mean for authors seeking to publish their work in Injury Prevention? Perhaps not a lot, but thinking from a decision science perspective might create new insights for some authors.

As a transformational journal, Injury Prevention is interested in supporting publication of quality science that makes a difference. Yes, the journal's pages serve as a repository of curated, high-quality scientific evidence easily retrievable as needed by researchers and practitioners alike. However, the greatest injury prevention impact of this scientific evidence will come from researchers able to present their results in form that easily fits into the decision-making processes.

I invite you to look through the pages of this issue from the perspective of a decision-maker. Have our authors got it right? How would you have presented their work if this was your research and you wanted to make sure people used your results as a basis for their decisions.

Funding The authors have not declared a specific grant for this research from any funding agency in the public, commercial or not-for-profit sectors.

Competing interests None declared.

Patient and public involvement Patients and/or the public were not involved in the design, or conduct, or reporting or dissemination plans of this research.

Patient consent for publication Not required.

Provenance and peer review Not commissioned; internally peer reviewed.

\section{(2) OPEN ACCESS}

Open access This is an open access article distributed in accordance with the Creative Commons Attribution Non Commercial (CC BY-NC 4.0) license, which permits others to distribute, remix, adapt, build upon this work non-commercially, and license their derivative works on different terms, provided the original work is properly cited, appropriate credit is given, any changes made indicated, and the use is non-commercial. See: http:// creativecommons.org/licenses/by-nc/4.0/.

(c) Author(s) (or their employer(s)) 2021. Re-use permitted under CC BY-NC. No commercial re-use. See rights and permissions. Published by BMJ.

\section{Check for updates}

To cite McClure RJ. Inj Prev 2021;27:207.

Inj Prev 2021;27:207.

doi:10.1136/injuryprev-2021-044268

ORCID iD

Roderick J McClure http://orcid.org/0000-0002-90678282 